\title{
Medical applications of RNA interference (RNAi)
}

\author{
Tiago Campos Pereira', Iscia Lopes-Cendes ${ }^{2^{*}}$ \\ From São Paulo Advanced School of Comparative Oncology \\ Águas de São Pedro, Brazil. 30 September - 6 October 2012
}

During its long and rich history, medical sciences have undergone several changes of paradigms. In this quest to develop more potent drugs, less invasive surgical techniques and more sophisticated diagnostic approaches (among other goals) medicine has contributed decisively to our well being and longevity. Some of these major accomplishments, which altered the course of humanity are: the development of antibiotics, organ transplantation and radiography. Medicine has recently reached a new hallmark: RNA interference (RNAi), a Nobel prize winning technology which promises to promote medical care at the molecular level, by regulating genes in our favor.

RNAi was first successfully used in C. elegans, a laboratory model species, by microinjecting dsRNAs in the worm's gonad. However, the works that laid the foundations for the development of the technique were initially done in plants and fungi. RNAi was accidentally discovered, when white transgenic petunias were obtained instead of deep purple ones [1]; a similar paradoxal result was obtained when white transgenic colonies of Neurospora $s p$ were observed in place of orange ones [2]. These findings revealed the existence of an unknown potent mechanism of gene regulation, which could be tamed for diverse uses, from basic science, agriculture, animal health and medicine.

From these seminal observations, during a period of nearly 10 years, researchers aimed at characterizing, at the genetic and biochemical levels, the process of RNAi. By the year 2001, scientists were ready to perform the initial analyses in human cells [3]. Since then, RNAi has been used as a tool in molecular biology, allowing potent and specific gene silencing. This is achieved by the introduction of double-stranded RNA molecules (dsRNAs), which ultimately lead to the degradation of messenger RNAs (mRNAs), i.e., gene silencing. The molecular

\footnotetext{
*Correspondence: icendes@unicamp.br

${ }^{2}$ Department of Medical Genetics, Faculty of Medical Sciences, University of Campinas - UNICAMP, Campinas, SP, Brazil

Full list of author information is available at the end of the article
}

mechanism behind RNAi requires the activation of an endogenous pathway which is present in almost all eukaryotic cells. This pathway is responsible for detecting long dsRNAs and, subsequently, promoting their cleavage by an enzyme called dicer, into small duplexes of approximately 21-25 bp called siRNAs (small interfering RNAs). Alternatively, siRNAs can be directly introduced into the cytoplasm of eukaryotic cells. This second approach is required in mammalian cells, since dsRNAs longer than $30 \mathrm{bp}$ induce apoptosis. siRNAs are subsequently transferred to a complex called RISC (RNAinduced silencing complex), where one strand of the duplex is destroyed and the other remains intact (designated guide strand). RISC then searches the cytoplasm for mRNA molecules with sequence complementarity to the guide strand. Once a mRNA with full complementarity is found, slicer (an endoribonuclease which is part of RISC) performs the cleavage of target mRNA [4].

Therefore, RNAi can be used as a technique that takes advantage of an endogenous biochemical pathway, directing it to the destruction of specific target transcripts (gene silencing). In addition, RNAi can be used to produce transgenic animals (known as knockdown animals), resembling the null phenotype $\left({ }^{-} /{ }^{-}\right)$. Additionally, since RNAi may be tamed to promote silencing efficiencies ranging from $0.1 \%$ to $100 \%[5,6]$, animals with partial phenotypes, known as hypomorfic, may generated. These hypomorfic individuals are very informative since they reveal intermediary and unprecedented phenotypes and because the null genetic construction may happen to be unviable [7].

Currently, most studies use RNAi as a tool for reverse genetics (identification of gene function), but the applications are numerous: i) disease control (viruses [8]; bacterial diseases [9]; parasites, [10]); genetic [11]; tumors [12], ii) production of animals of commercial interest [13] and iii) production of animal models for research use [14]. Other possible future applications include: control of drug 
consumption [15], pain relief [16], modulation of sleep [17], among many others.

Another relevant feature of RNAi is its temporary effect - long lasting knockdown is only observed in C. elegans and a few other species. Therefore, in order to study genes with constitutive expression, it is necessary to combine long-term strategies such as the production of transgenic animals encoding shRNAs (similar to siRNAs) or the use of viral vectors. On the other hand, this transitory characteristic can also be used as an advantage, when one considers RNAi as a therapetical strategy.

Furthermore, the control of gene expression via RNAi can be modulated in time and directed to specific cells or organs. The identification of viral proteins capable of suppressing RNAi, such as p19 [18] allows for future applications, as well as the use of inducible promoters (high temperature, drugs).

All these new developments have recently led to the first published human clinical trials with very promising results [19].

\section{Competing interests}

There are no competing interests in this presentation.

\section{Author details}

'Department of Biology, Faculty of Philosophy, Sciences and Languages of Ribeirao Preto, University of Sao Paulo - USP, Ribeirao Preto, SP, Brazil.

${ }^{2}$ Department of Medical Genetics, Faculty of Medical Sciences, University of Campinas - UNICAMP, Campinas, SP, Brazil.

Published: 4 April 2013

\section{References}

1. Napoli C, Lemieux C, Jorgensen R: Introduction of a Chimeric Chalcone Synthase Gene into Petunia Results in Reversible Co-Suppression of Homologous Genes in trans. Plant Cell 1990, 2(4):279-289.

2. Romano N, Macino G: Quelling: transient inactivation of gene expression in Neurospora crassa by transformation with homologous sequences. Mol Microbiol 1992, 6(22):3343-53.

3. Elbashir SM, Harborth J, Lendeckel W, Yalcin A, Weber K, Tuschl T: Duplexes of 21-nucleotide RNAs mediate RNA interference in cultured mammalian cells. Nature 2001, 411(6836):494-8.

4. Hutvágner G, Zamore PD: A microRNA in a multiple-turnover RNAi enzyme complex. Science 2002, 297(5589):2056-60.

5. Khvorova A, Reynolds A, Jayasena SD: Functional siRNAs and miRNAs exhibit strand bias. Cell 2003, 115(2):209-16, Erratum in: Cell 2003, 14;115 (4):505.

6. Schwarz DS, Hutvágner G, Du T, Xu Z, Aronin N, Zamore PD: Asymmetry in the assembly of the RNAi enzyme complex. Cell 2003, 115(2):199-208.

7. Palliser D, Chowdhury D, Wang QY, Lee SJ, Bronson RT, Knipe DM, Lieberman J: An siRNA-based microbicide protects mice from lethal herpes simplex virus 2 infection. Nature 2006, 439(7072):89-94.

8. Escobar MA, Civerolo EL, Summerfelt KR, Dandekar AM: RNAi-mediated oncogene silencing confers resistance to crown gall tumorigenesis. Proc Natl Acad Sci USA 2001, 98(23):13437-42.

9. Pereira TC, Pascoal VD, Marchesini RB, Maia IG, Magalhães LA, ZanottiMagalhães EM, Lopes-Cendes I: Schistosoma mansoni: evaluation of an RNAi-based treatment targeting HGPRTase gene. Exp Parasitol 2008, 118(4):619-23.

10. Raoul C, Abbas-Terki T, Bensadoun JC, Guillot S, Haase G, Szulc J, Henderson CE, Aebischer P: Lentiviral-mediated silencing of SOD1 through RNA interference retards disease onset and progression in a mouse model of ALS. Nat Med 2005, 11(4):423-8.
11. Ptasznik A, Nakata Y, Kalota A, Emerson SG, Gewirtz AM: Short interfering RNA (siRNA) targeting the Lyn kinase induces apoptosis in primary, and drug-resistant, BCR-ABL1(+) leukemia cells. Nat Med 2004, 10(11):1187-9.

12. Minton $\mathrm{K}:$ In the news: Allergen-free cats (Research Highlight). Nature Rev Immunol 2004, 4:926.

13. Peng $S$, York JP, Zhang P: A transgenic approach for RNA interferencebased genetic screening in mice. Proc Natl Acad Sci USA 2006, 103(7):2252-6.

14. Lasek AW, Janak PH, He L, Whistler JL, Heberlein U: Downregulation of mu opioid receptor by RNA interference in the ventral tegmental area reduces ethanol consumption in mice. Genes Brain Behav 2007, 6(8):728-35.

15. Kim SJ, Lee WI, Lee YS, Kim DH, Chang JW, Kim SW, Lee H: Effective relief of neuropathic pain by adeno-associated virus-mediated expression of a small hairpin RNA against GTP cyclohydrolase 1. Mol Pain 2009, 5:67.

16. Chen L, McKenna JT, Bolortuya Y, Winston S, Thakkar MM, Basheer R, Brown RE, McCarley RW: Knockdown of orexin type 1 receptor in rat locus coeruleus increases REM sleep during the dark period. Eur J Neurosci 2010, 32(9):1528-36.

17. Vargason JM, Szittya G, Burgyán J, Hall TM: Size selective recognition of siRNA by an RNA silencing suppressor. Cell 2003, 115(7):799-811.

18. DeVincenzo J, Lambkin-Williams R, Wilkinson T, Cehelskyd J, Nochur S, Walsh E,Meyersd R, Gollob J, Vaishnaw A: A randomized, double-blind, placebo-controlled study of an RNAi-based therapy directed against respiratory syncytial virus. Proc Natl Acad Sci USA 2010, 107(19):8800-05.

19. Davis ME, Zuckerman JE, Choi CH, Seligson D, Tolcher A, Alabi CA, Yen Y, Heidel JD, Ribas A: Evidence of RNAi in humans from systemically administered siRNA via targeted nanoparticles. Nature 2010, 464(7291):1067-70.

doi:10.1186/1753-6561-7-S2-K21

Cite this article as: Pereira and Lopes-Cendes: Medical applications of RNA interference (RNAi). BMC Proceedings 2013 7(Suppl 2):K21.

\section{Submit your next manuscript to BioMed Central and take full advantage of:}

- Convenient online submission

- Thorough peer review

- No space constraints or color figure charges

- Immediate publication on acceptance

- Inclusion in PubMed, CAS, Scopus and Google Scholar

- Research which is freely available for redistribution 